\title{
Uneven Development and Pakhtun Diaspora in Karachi (Pakistan)
}

\author{
Tarique Niazi ${ }^{1}$
}

Karachi is now home to seven million Pakhtuns (Obaid-Sharmeen, 2009; National, 2009), who constitute $38 \%$ of the city's population of $18 \mathrm{~m}$ (Yusuf, 2012). It is projected to become a Pakhtun-majority city by 2045 (Baloch, 2014). The city's Pakhtun population already exceeds the combined population of Kandahar, Peshawar and Quetta, the world's three largest Pakhtun-majority cities. Karachi's growing diversity, however, has engendered distributive conflicts (Hina, 2003), dividing urban communities along ethnic, linguistic, regional and religious identities. Structures of discrimination and warped power relations have further fueled atavistic identity politics. As a result, Pakhtuns experience discrimination in the city's putative exclusionary development that results in their economic, occupational, residential and social segregation, a fact that can be seen as wages of uneven development. Yet Pakhtun diaspora in Karachi has been underresearched, especially with regard to the structural dynamics of development and underdevelopment in Pakistan and the impact of both on urban growth. Deploying the uneven and combined development theory, this paper argues that Pakistan's development project, modeled on neoclassical economic and modernization perspectives, generated underdevelopment that displaced what Marx called the "relative surplus population" (Nielson and Stubbs, 2011) from underdeveloped regions, and parked it into overdeveloped urban centers. Empirically, the paper concentrates on Karachi that is the country's most developed city, and Khyber-Pakhtunkhwa that is one of the two most underdeveloped provinces of Pakistan. The co-existence of development and underdevelopment (i.e., combined development) across Pakistan's subnational spaces is problematized. Specifically, Khyber-Pakhtunkhwa's chronic underdevelopment and concomitant Pakhtun out-migration are shown to be causally related. [Article copies available for a fee from The Transformative Studies Institute. E-mail address: journal@transformativestudies.org Website: http://www.transformativestudies.org (C2016 by The Transformative Studies Institute. All rights reserved.]

KEYWORDS: Uneven Development, Colonialism, Capitalism, Pakhtun Diaspora, Distributive Conflicts, Discrimination, Identity Politics, Racism, Segregation, Karachi, Khyber-Pakhtunkhwa.

\footnotetext{
${ }^{1}$ Tarique Niazi, Ph.D., is an Associate Professor of Environmental Sociology at University of Wisconsin at Eau Claire. He specializes in environmental conflicts and security. The author would like to thank Dr. Ali Haider Zaidi for his exceedingly helpful comments and editorial suggestions during the review process and early revisions of this paper. Address correspondence to: Tarique Niazi, University of Wisconsin, Eau Claire, WI 54702; Tel: 715-836-3168; e-mail: niazit@uwec.edu.
} 